\title{
Dolphins Inhabiting in Black Sea and Effects on Fisheries
}

\author{
Karadeniz'de Yaşayan Yunus Türleri ve Balıkçılığa Etkileri
}

\author{
Research Article \\ ismet Balık \\ Ordu University, Fatsa Faculty of Marine Sciences, Department of Maritime Business Administration, Ordu, Turkey.
}

\section{A B STR ACT}

$B_{\text {id }}^{\text {id }}$ iodiversity in the Black Sea is low mostly due to the geographical isolation and low salinity, high hypoxic amount and anoxic bottom waters of 100-250 m depth as well. Therefore, only the three dolphin species; the harbour porpoise (Phocoena phocoena), common dolphin (Delphinus delphis) and bottlenose dolphin (Tursiops truncatus) live in the Black Sea region. In this study, the biological characteristics, ecological requirements and habitats of these species are reviewed, effect on both ecosystem and fisheries are evaluated. Many species of the marine mammals are negatively effected by anthropogenic factors and as a result given in the Red List" by the the World Conservation Union (IUCN) where; Delphinus delphis is stated as least compromised (LC), he Mediterranean sub-population is stated as endangered (EN), Phocoena phocoena is stated as least compromised (LC), Tursiops truncatus is stated as least compromised (LC) and Mediterranean subpopulation of Tursiops truncatus is stated as sensitive (VU). Unintentional catch of dolphins, mostly resulting in death or killing of these species, by turbot nets having 280-360 mm mesh size is one of the leading anthropogenic factors. Besides, dolphins' stealing fish particularly from the bottom gillnets with 32-44 mm mesh size and destroying these nets have a negative impact on fishing.

\section{Key Words}

Black Sea, Fisheries, Dolphin, Delphinus delphis, Tursiops truncatus, Phocoena phocoena.

\section{ÖZET}

B aşta coğrafik izolasyon olmak üzere düşük tuzluluk, yüksek hipoksik miktarı ve derinliği 100-250 m'nin altındaki suların anoksik olması nedeniyle Karadeniz'deki biyolojik çeşitlilik düşüktür. Bu nedenle yalnızca mutur (Phocoena phocoena), kısa gagalı yunus (Delphinus delphis) ve afalina (Tursiops truncatus) olmak üzere üç yunus türü yaşamaktadır. Sunulan bu çalışmada türlerin biyolojik özellikleri, ekolojik istekleri, yaşam alanları üzerinde durulmuş, gerek ekosisteme gerekse balıkçılığa etkileri üzerine değerlendirmeler yapılmıştır. Deniz memelileri gibi birçok türün özellikle antropojenik etmenler sonucunda olumsuz olarak etkilenmesinden dolayı Dünya Koruma Birliği (IUCN) tarafından "Kırmızı Liste" de Delphinus delphis türü en az tehlikede (LC), Akdeniz alt popülasyonu ise soyu tehlike altında (EN) olarak, Phocoena phocoena türü en az tehlikede (LC), Tursiops truncatus türü en az tehlikede (LC), Tursiops truncatus türünün Akdeniz alt popülasyonu ise hassas (VU) şeklinde belirtilmiştir. 280-360 mm ağ göz açıklığına sahip kalkan ağlarıyla gerçekleştirilen balıkçılıkta, yunusların istenmeden avlanması ve büyük olasılıkla ölmesi ya da öldürülmesi bu etkilerin başında gelmektedir. Ayrıca, özellikle 32-44 mm ağ göz açıklığına sahip dip uzatma ağlarıyla yapılan avcılıkta, yunusların ağlara yakalanmış balıkları çalması ve bu sırada ağları parçalaması da balıkçılık üzerinde olumsuz bir etkiye yol açmaktadır.

\section{Anahtar Kelimeler}

Karadeniz, Balıkçılık, Yunus, Delphinus delphis, Tursiops truncatus, Phocoena phocoena.

Article History: Received: Jun 22, 2015; Revised: Mar 2, 2016; Accepted: Mar 20, 2016; Available Online: Apr 1, 2016.

Dol: 10.15671/HJBC.20164418127

Correspondence to: İ. Balık; Ordu University, Fatsa Faculty of Marine Sciences, Ordu, Turkey. 


\section{INTRODUCTION}

$\mathrm{M}$ arine mammals are a taxon passed from lands to aquatic ecosystems, origin of life, during the evolution and adapted to this environment. According to taxonomic classification, this group in animal kingdom comprises Sirenia, Carnivora and Cetacea orders including 5.36 and 83 species respectively. These species locating on the top of the food web of aquatic ecosystems have been interacting with human in many ways.

In ancient times, some of these species, such as the Mediterranean monk seal, Monachus monachus was hunted for its meat and skin while its organs and body fluids were used for medical purposes in that era. They had been the subject of the folk tales and superstitions as well. During the same era, however, the dolphins were seen as heros saving fisherman from drowning, children's playmate and music lovers and inspired ceramics money, mosaic, sculpture and fresco artists. With the discovery of new continents and the industrial revolution, these species were seen as an economical input and regularly hunted, consequently, during the last two centuries, many species showed a serious decrease in population and some of the species and the local populations became even extinct.

In addition, as they reflect the disruptions in the food web (pollution, decline of fish stocks/decrease), some of its species became endangered and due to its interaction with fisheries dolphins have become the hot topic of scientific researches and the conservation attempts during the last twenty years while the public is informed about their situation with the introduction of descriptions such as the "Flag Species" expressing their environmental importance.

The Black Sea is one of the most remarkable regional seas in the world. It is almost cut off from the rest of the world's seas, is over 2200 $\mathrm{m}$ deep and receives the drainage from a 1.9 million $\mathrm{km}^{2}$ basin covering about one third of the area of continental Europe. Its only connection to the world's oceans is through the Istanbul Strait, a $35 \mathrm{~km}$ natural channel, as little as $40 \mathrm{~m}$ deep in places. This channel has a two layer flow, carrying about $300 \mathrm{~km}^{3}$ of seawater to the Black Sea from the Mediterranean along the bottom layer and returning a mixture of seawater and freshwater with twice this volume in the upper layer. Every year, about $350 \mathrm{~km}^{3}$ of river water enters the Black Sea from land in over twenty countries: Albania, Austria, Belarus, Bosnia and Herzegovina, Bulgaria, Croatia, Czech Republic, Georgia, Germany, Hungary, Italy, Macedonia, Moldova, Montenegro, Poland, Romania, the Russian Federation, Serbia, Slovakia, Slovenia, Switzerland, Turkey and Ukraine. Europe's second, third, fourth and sixth largest rivers the Danube, Dnipro, Don (indirectly via the Sea of Azov) and Dniester all flow to the Black Sea [1].

The Black Sea has a long history of cetacean fishery. Before petroleum based industries were developed, dolphin oil was essential for the people of the Black Sea. They used it for pharmacy, lamp oil, currier's oil, engine oil, lubricating oil, drugs containing vitamin $D$, albumin, paints, varnishes, soap, cosmetics, tinned meat and sausage, leather shoe wares, fish meal as a feed to poultry, bone fertilizer and glue in all Black Sea countries $[2,3]$. It is known that the Black Sea cetacean fishery begun in 1870 in the USSR and Turkey followed the course in the 1930's [4]. After the cetacean fishery banned in Turkey they used bycatch cetaceans in bottom nets until the 1990's. They used harbour porpoises more than common dolphins and bottlenose dolphins (max. 5\%), because the porpoises provided oil of better quality and quantity. There were two more primitive plants producing small amount of oil in Yakakent. They sold to Gaziantep (south eastern of Turkey) for leather production and to Samsun Vezirköprü [5].

According to Slastenenko [6], the first oil mill was established in Sukhumi in 1882, the second one in Pitsunda in 1883. The first plants of oil extraction were founded in Trabzon at the beginning of the 1800s. Meat and Fish Institution (EBK) Meal and Oil Factory was established in Trabzon in 1952 and was modernized in 1962, enough to process 100 t per day $[4,7]$.

In the 20th century, the abundance of Black Sea cetaceans was considerably reduced by 
massive direct killing. Mass legal killing of Black Sea dolphins and porpoises peaked in the 1930s and 1950s; it was banned in 1966 in the USSR, Bulgaria and Romania, and in 1983 in Turkey. Currently, the most obvious threats affecting Black Sea cetacean populations are accidental mortality in fishing gear; habitat degradation causing the reduction of prey resources; water pollution and epizootics resulting in cetacean mass mortality events. All these factors are directly or indirectly dependent on enhanced (and poorly managed) human activities in the sea and in the entire Black Sea Basin [3].

Hunting of marine mammals has been strictly forbidden in Turkey since 1983, and they are protected firstly by fisheries law of 1380 and the international agreements our country involved in, Barcelona Convention and it sub-protocols.

\section{Dolphin Species Living in The Black Sea}

There are 20 different cetacean species known in the Black and Mediterranean Sea basins living permanently or temporarily. Although some of them are rarely observed, a total of 10 species are living in Turkey seas while only 3 species live in Black Sea. Cetacean species living in Black Sea are the harbour porpoise (Phocoena phocoena), the short-beaked common dolphin (Delphinus delphis) and the common bottlenose dolphin (Tursiops truncatus) [3]. In general, the biodiversity of the Black Sea is quite limited due to the geographic isolation, low salinity, high amount of hypoxic and anoxic waters below the 100-250 m depth [8].

Because many species such as marine mammals especially as a result of anthropogenic factors are adversely affected, danger degree of generations of the species living in the Black Sea is specified as species Delphinus delphis, Phocoena phocoena and Tursiops truncatus are at least endangered (LC) in this list which is defined as "Red List" by The World Conservation Union (IUCN) and is prepared for each taxon by "Species Specialist Group". As the top predators of the Black Sea, Cetaceans are faced with several threats such as accidental catch in fishing gear (bycatch), habitat degradation causing the reduction of prey resources, marine pollution and epizootics resulting in Cetacean mass mortality events [3].

\section{Phocoena phocoena (Linnnaeus, 1758) "Harbour Porpoise"}

Three sub-species of Phocoena phocoena are known as P. phocoena phocoena (North Atlantic), $P$. phocoena relicta (Black Sea), $P$. phocoena vomerina (North Pacific). Porpoises live in cold climates and subpolar waters of the northern hemisphere at an average temperature of $15^{\circ} \mathrm{C}$. They occasionally wander in deep waters far from land and usually are found in shallow waters and mostly close to the shore. They can be observed in the breakish low-saline waters of bays, lagoons and estuaries. This species lives only in Marmara and the Black Sea regions of the Mediterranean Sea basin. There have been records of sightings and strandings in the Turkish Strait System, especially in the Istanbul Strait and the northern part of the Marmara Sea but also in the middle of the Marmara Sea and Çanakkale Strait [9-12]. It is known that the Muture passes to the Azov Sea in the spring and to the Marmara Sea April-May. They return to Black Sea in September-October period.

In the 20th century, the number of Black Sea harbour porpoises was dramatically reduced by massive direct killing for the cetacean-processing industry that continued until 1983 [13]. In 1990s, however, the bottlenose dolphin has become prevalent in inshore waters of the northern Black Sea [14]. It was estimated that sighting score of bottlenose dolphins increased five times in 1997 and 1998 in comparison with 1995, whereas the number of harbour porpoises on record declined dramatically. Mass incidental mortality in bottom-set gill nets was the most likely cause of the marked decrease in harbour porpoise abundance [15-16]. It was reported in IUCN [17] that the total population size of this species in the Black Sea is unknown. However, some estimates suggest that population size is at least several thousands or possibly even the low tens of thousands.

\section{Tursiops truncatus (Montagu, 1821) "Bottlenose Dolphin"}

There are different opinions among scientists about the Tursiops truncatus (Bottlenose dolphin), either it has only one species or it can be divided into more. Some zoologists mention 3 species of Bottlenose dolphin; Atlantic afalina (Tursiops 
truncatus), Indopasific afalina (Tursiops aduncus) and Pacific afalina (Tursiops Gilli). It has a dark grey dorsal, light gray lateral and white ventral sides. Light gray extension on the lateral side of the body under the dorsal fin is characteristic for this species. A rough melon is easily recognized and it has a short nose. Dorsal fin is sickle shaped. They live in coastal areas in tropical and warm waters and they also live as oceanic in the eastern tropical Pacific. They live in Aegean, Marmara and Black Sea coasts of Turkey. They live in coastal waters but sometimes they are observed in offshore waters of the Black Sea. They intensify in the western Black Sea during April and November period.

Yaskin and Yukhov [18] indicated that the population size of $T$. truncatus is unclear in spite of numerous estimates accomplished in the former USSR and Turkey before the mid-1990s. Nevertheless, the abundance of bottlenose dolphins was considered as the smallest of the three cetacean populations in the Black Sea during most of the 20th century. However, bottlenose dolphins became relatively prevalent in coastal waters of the northern Black Sea round the Crimea peninsula in the last quarter of the 1990s. According to IUCN [17] workshop report, total population size unknown but may be in the low 10,000 s based on observed densities in areas that have been surveyed.

\section{Delphinus delphis Linnaeus, 1758 "Common Dolphin"}

Three known species of the genus Delphinus are Delphinus delphis, D. capensis and D. tropicalis [19]. Dorsal is black and dark gray while the ventral is white. Yellow-orange coloration is distinguished at lateral sides toward the front of the body. A "V" shape is observed under the dorsal fin that joins with the gray lines on the caudal peduncle forming the hourglass like coloration which is characteristic for this species. These are ocean animals inhabiting in the tropical and warm waters of $10-20^{\circ} \mathrm{C}$ of the world. The range of the Black Sea common dolphin population is represented by the almost entire Black Sea including territorial waters and exclusive economic zones of Bulgaria, Georgia, Romania, Russia, Turkey and Ukraine, and internal waters of Ukraine in Karkinitsky Bay [20]; and by internal waters of Turkey including the Bosporus Strait and Marmara Sea [21]. Common dolphins do not occur in the Azov Sea and normally avoid the Kerch Strait, although a single live stranding was recorded there in 1994 at the time of morbillivirus epizootic [22]. There is no reliable information on $D$. delphis presence on possible two-way transit between the Black Sea and Mediterranean Sea through the Turkish Straits System [3]. They are negatively affected by the pelagic fishing carried out by seine net and gill net fishing. Excessive commercial fishing of their preys severely affected this species. Common dolphins are sometimes caught by fishing nets.

For the last 30 years, it is reported that the biodiversity of the Black Sea has been seriously affected due to the anthropogenic damage on its drainage basin. Species composition of many communities changed either by excessive increase or decrease of the some organisms. Mediterranean monk seal totally disappeared from the Black and the Mediterranean Seas. Black Sea dolphins had been violently affected by the commercial hunting of dolphins which continued till 1980s [23].

According to IUCN [17], the population size of this species is unknown. However, the results of survey nevertheless suggest that the current total population size is at least several 10.000s, and possibly 100.000 or more

\section{Dolphins-Fisheries Interaction}

The main catching gear used by all the Black Sea countries was the surrounding net until the 1950's [7]. This catching gear has transferred to Russian from Turks which had used for hundreds of years on Caucasian coast (eastern Black Sea). Turkish fishermen used surrounding nets are known as alamana, which were 800-1500 m in length, 100 $\mathrm{m}$ in height and 8-12 cm mesh size (bar length). Cetacean catching with surrounding nets was the most earliest and most efficient. There was a record that 1500 common dolphins were caught at a time [6].

In the past, the most important factor for the depletion of cetacean populations was commercial dolphin fishery. Mass legal killing (= devas- 
tating overexploitation) of Black Sea dolphins and porpoises peaked in the 1930s and 1950s; it was banned in 1966 in the USSR, Bulgaria and Romania, and in 1983 in Turkey. Currently, the most obvious threats affecting Black Sea cetacean populations are accidental mortality in fishing gear; habitat degradation causing the reduction of prey resources; water pollution and epizootics resulting in cetacean mass mortality events. All these factors are directly or indirectly dependent on enhanced (and poorly managed) human activities in the sea and in the entire Black Sea Basin [3].

Cetaceans are known to become entangled in many gear types, including long-lines, drift nets, trap lines and midwater trawls, but the largest problem remains with coastal gill nets, drift nets and purse-seine nets. The continued use of gill nets is endangering a number of coastal species of dolphin and porpoise. Global fisheries are increasing in intensity and range. The introduction of more sustainable fishing techniques can reduce this pressure. However, the use of destructive fishing methods and the growth of many modern commercial fisheries continues to impact many cetacean populations around the world. The impacts can be both direct through bycatch and indirect through loss of prey species [24].

Interactions between cetaceans and fisheries in the Mediterranean Sea are probably as old as the first human attempts to catch fish with a net [25]. Interactions between cetaceans and coastal fisheries may negatively affect the fisheries through: adamage to fishing gear in the form of holes torn in the nets as the dolphins attempt to remove fish, or other forms of gear damage caused by cetaceans; b- reduction in the amount or value of the catch as the dolphins mutilate or remove caught fish from nets or longlines; c- reduction in the size or quality of the catch as the dolphins' presence causes fish to flee from the vicinity of the nets; $d$ - time, money, or gear loss by fishermen due to cetaceans interacting with fishing operations, or getting caught in nets; e- a real or perceived ecological competition with cetaceans, based on the conviction that depredation - particularly by dolphins - reduces the amount of fish available to fisheries [26].
Neither killing nor catching of the dolphins will solve the Black Sea problems related with the fisheries-marine mammals interaction. Private property conflict continues between these two groups due to the similar but competitive survival needs to fish where they catch at the same regions and at the same time periods. Unsystematic indicators of beneficial cooperation between Black Sea fisherman and dolphins have been known for long time [27], conflicts resulting in mutual damage to marine mammals and fisheries have still been reported in all Black Sea countries [28].

Very few reliable information is found about the influence of aquatic mammals on commercial fisheries over the Black Sea and the neighboring seas. Except for the prejudiced guess of annual fish consumption based on assumed theoretical total population of dolphins, there is no specific research. All predictions related to the period between 1940 and 1960, due to the use of incorrect data as a basis for the dolphin population and its daily value, suspiciously showed that the dolphins were a main threat for the fisheries as they were guilty for the consumption of fish. Bushuyev [29] revised these calculations by using more realistic numbers on feeding rates of dolphins, in 1980s, Bushuyev claimed that the total annual fish consumption of the dolphins is considerably less than the total harvest of Black Sea fisheries. Despite the lack of reliable evidence, dolphins are persistently blamed of the damage to the Turkey fisheries [30-32].

Above thirty fish species are determined in the stomach contents of dolphins living in the Black Sea and the Sea of Azov except for Crimea and Caucasian coasts (Ukraine, Russia and Georgia waters). Birkun [16] reported that this study included 120 individuals which had been killed intentionally between 1930s and 1950s and thousands of accidentally captured or stranded dolphins during 1990s [33]. Some of the preys determined to be very important in dolphins' diet have also priority in fisheries. Especially, small benthics (Merlangius merlangus euxinus and Gobiidae species) and fishes forming pelagic 
herds (Engraulis encrasicolus ponticus, Sprattus sprattus phalaericus) constitute fundamental nutrition of Phocoena phocoena (mutur), for anchovy and sprat there is an appreciable competition between mutur and fisherman. Sprat and anchovy may also bring out a conflict between pelagic trawling nets and Delphinus delphis. Tursiops truncatus feeding habits mainly interact with coastal fishing of turbot and gray mullet. There is no reliable data showing negative effects of these type of competitions in fisheries. It is believed that the effect of marine mammals on Black Sea anchovy abundance is unimportant compared to the anthropogenic threats on plankton sources feeding fishes [34].

Birkun [32] reported that, interviews with the heads of some of the fisheries cooperatives and fishermen in Ukraine, Bulgaria and Georgia showed that neither militant haters of marine mammals nor a serious competition between fishermen and these creatures exists. There aren't any requests of the coastal fisherman regarding dolphins, however a displeasure generally due to the accidental catch of Phocoena phocoena is stated and they also mentioned that the problem is growing as the Tursiops truncatus damages nets and fish on the nets or steals from the net. The very same problem is also known to occur in Turkey coasts.

Some effects of fisheries on Black Sea mammals can been summarized as; the changes like increase or decrease of search possibilities for feeding, behavioral changes, breakdown of habitats, fatal or non-fatal injuries caused by fishing gears, changes in distribution, migration and reproduction capabilities. The effect of fisheries on feeding sources can be explained as; over-exploitation carried out by pelagic and coastal fishing of main prey species of Phocoena phocoena, Delphinus delphis ve Tursiops truncatus which may affect the population of the Black Sea marine mammals. Overfishing, eutrophication and outbreaking of invasive species (Mnemiopsis leidyi) led up to a quick decrease in anchovy and sprat abundance.

As a result, the commercial catch of sprat decreased almost eight factor (from 105.200 tons in 1989 to 13800 tons in 1993) and the total commercial catch of the anchovy decreased twelve times (from maximum 468.800 tons in 1987-1988 fisheries season to 39.100 tons in 1990-1991 fisheries season). Negative tendency in abundance, was observed in Lisa spp., Mugil cephalus and turbot, especially in North Black Sea section where both legal and illegal fisheries pressure is reported [32].

\section{RESULTS}

Fishermen argue that stocks of many fish species in the Turkish coasts of Black Sea were decreased because of increasing dolphin population particularly in last decade. For this reason, they demanding to be decreased of the Black Sea dolphins. The population trends of the Black Sea dolphins are not known accurately. The last population survey was made in 1987 off the Turkish coast and an estimated total population of three species combined was 454.440 individuals [35]. Stocks in the Black Sea dolphins should be re-estimated and must be constantly monitored. The present state of Black Sea cetacean populations is not quite clear or encouraging in spite of certain research and conservation progress achieved during last decade, since the two essential instruments have been adopted in 1996 - the Agreement on the Conservation of Cetaceans of the Black Sea, Mediterranean Sea and Contiguous Atlantic Area (ACCOBAMS), and the Strategic Action Plan for the Rehabilitation and Protection of the Black Sea (BS SAP). The insufficiency of scientific information includes population abundance, distribution, migrations, critical habitats, anthropogenic and natural threats as well as some basic aspects of life history and pathology [3].

According to predictions, decline in feeding sources resulted due to decrease in prey species has a strong effect on delphinus and mutur [29]. Mugil souiy entering to the Black Sea is an example the impact on fisheries and feeding of mammals. Entrance of this species originating from Japan Sea started within the lagoons and coastal waters (in Northwest Black Sea and Azov Sea) during 1972 to 1984 period. By late 1980s this fish became abundant and common through 
the whole region. Nowadays, this fish is caught in all of the Black Sea countries. The diets of Tursiops truncatus and less common mutur involves this new species.

After all, in order to prevent unintentional catch of dolphins by nets (bycatch), dolphins stealing fishes from the net (depredation) and damaging the nets, various researches aiming to keep dolphins away from the nets by the use of acoustic repellents were performed. Some studies about the unintentional catch of dolphins (bycatch) were carried out in the Black Sea region, however only few studies focused on the use of acoustic repellents. Further researches are necessary to decrease the damage of dolphins to the commercial fishing which becomes the most significant problem of the Black Sea fisherman in recent years and to prevent the death of dolphins related to fisheries.

\section{References}

1. CPBSAP, Strategic Action Plan for the Environmental Protection and Rehabilitation of the Black Sea, The Commission on the Protection of the Black Sea Against Pollution, Bulgaria, 17 April (2009), 70 p.

2. A. Acara, Evaluation of Black Sea dolphins in the industry. Hidrobiyoloji Mecmuası. Istanbul University Hydrobiology Research Institute Publications, Vol 3, No 1.1965. Istanbul.

3. A. Jr. Birkun, The state of cetacean populations. (ed. T. Oğuz), State of the Environment of the Black Sea (2001-2006/7). Publication of the Commission on the Protection of the Black Sea Against Pollution (BSC), Istanbul, Turkey, 2008, pp. 365-395.

4. A.M. Tonay, A. Amaha Öztürk, Historical records of cetacean fishery in the Turkish seas. J. Black Sea/ Mediterranean Environment, 18 (2012) 388-399.

5. H. Arpa, Short stories about fishmen and fisheries from Yakakent. Yakakent Municipality Culture Publications, Samsun, 2012, 328 p.

6. E.P. Slastenenko, Black Sea Dolphins. Hidrobiologi Mecmuası, Istanbul University Hydrobiology Research Institute Publications Serial A, 3 (1955) 68 89.

7. M. Yel, E. Özdemar, A. Amaha, N. Miyazaki, Some aspects of dolphin fishery on the Turkish Coast of the Black Sea. In: (ed., B. Öztürk), Proceedings of the First International Symposium on the Marine Mammals of the Black Sea, İstanbul, 1996, pp. 31-40.

8. A. Birkun, Jr., The current status of bottlenose dolphins (Tursiops truncatus) in the Black Sea. The review is based on the document presented at the 1st Meeting of the Parties of the Agreement on the Conservation of Cetaceans of the Black Sea, Mediterranean Sea and Contiguous Atlantic Area (Monaco, 28 February-2 March 2002).
9. A. Dede, A.A. Ozturk, A.M. Tonay, Cetacean surveys in the Istanbul (Bosphorus) Strait in 2008. In: G.J. Pierce, E. Philips, R. Lick (Eds.), Proceedings CD of 22nd Annual Conf. European Cetacean Society, Egmond aan Zee, the Netherlands, 2008.

10. A.A. Ozturk, A. Dede, A.M. Tonay, B. Ozturk, Cetacean surveys in the Istanbul (Bosphorus) Strait in 20072008. In: Abstracts of 23rd Annual Conf. European Cetacean Society, Istanbul, Turkey, 2009.

11. A.M. Tonay, A. Dede, A.A. Ozturk, B. Ozturk, Cetacean strandings in the Turkish Straits System (TSS) and the Northern Aegean Sea coast of Turkey during 1999-2008. In: Proc. 23rd Annual Conf. European Cetacean Society, Istanbul, Turkey, 2009.

12. A. Dede, Marine mammals of the Marmara Sea. In: B. Ozturk (Ed.), Proceedings of the Symposium 'The Marmara Sea 2010', Turkish Marine Research Foundation Publications no: 32, 2010, pp. 272-281.

13. IWC, Annex L. Report of the Sub-committee on Small Cetaceans. J. Cetacean Res. Manage. 6 (Suppl.) (2004) 315-334.

14. A. Jr. Birkun, S. Krivokhizhin, K. Kosova, Bottlenose dolphin (Tursiops truncatus) became prevalent cetacean species in Black Sea coastal waters off the Crimea. P. 409 In: P.G.H. Evans and E. O'Boyle (Eds.), European research on cetaceans - 15 (Proc. 15th Annual Conf. European Cetacean Society, Rome, Italy, 6-10 May 2001). ECS, Kiel, (2004b) 478 pp.

15. A. Jr. Birkun, S.V. Krivokhizhin, V.Y. Gridin, A.V. Zhbanov, A.V. Zanin, I.V. Masberg, Strandings of neonate Black Sea harbour porpoises (Phocoena phocoena) as a probable consequence of the nursing females' death in fishing gear. In: Marine Mammals of the Holarctic: Collection of Scientific Papers after the 3rd Internat. Conf., pp. (2004a) 59-64, Koktebel, Ukraine, 11-17 October 2004, Moscow, 609 pp.

16. A. Jr. Birkun, Bottom-set gillnet fisheries and harbour porpoises in the Black Sea: High-tech against cetaceans. FINS (the Newsletter of ACCOBAMS), 2(1) (2005) $10 \mathrm{pp}$.

17. IUCN, The Status and Distribution of Cetacean in the Black Sea and Mediterranean Sea. Workshop report, Monaco 5-7 March, 2006.

18. V.A. Yaskin, V.L. Yukhov, The numbers and distribution of Black Sea bottlenose dolphins. In: V.E. Sokolov and E.V. Romanenko (Eds.), The Black Sea Bottlenose Dolphin Tursiops truncatus ponticus: Morphology, Physiology, Acoustics, Hydrodynamics, pp. 19-26, Nauka, Moscow. 1991. 672 pp.

19. D. W. Rice, Marine Mammals of the World: Systematics and Distribution. Special Publication Number 4. Society for Marine Mammalogy, Lawrence, KS, 1998.

20. A. Jr. Birkun, Cetaceans (Cetacea). In: Y.P. Zaitsev et al. (Eds.), The North-Western Black Sea: Biology and Ecology. Naukova Dumka, Kiev. 2006. 703 pp.

21. B. Öztürk, A.A. Öztürk, Preliminary study on dolphin occurrence in Turkish straits system. In: P.G.H. Evans, E.C.M. Parsons and S.L. Clark (Eds.), European research on cetaceans-11, (Proc. 11th Annual Conf. European Cetacean Society, Stralsund, Germany, 1012 March 1997), ECS, Kiel., 1997.

22. A. Jr. Birkun, Kuiken, T. Krivokhizhin, S. Haines, A.D.D.M Osterhaus, M.W. van de Bildt, C.R. Joiris, and U. Siebert, Epizootic of morbilliviral disease in common dolphins (Delphinus delphis ponticus) from the Black Sea. Veterinary Records 144(4) (1999) 8592. 
23. A. Birkun, Jr., Cetacean habitat loss and degradation in the Black Sea. In: G. Notarbartolo di Sciara (Ed.) Cetaceans of the Mediterranean and Black Seas: state of knowledge and conservation strategies. A report to the ACCOBAMS Secretariat, Monaco, February 2002, Section 8, $19 \mathrm{p}$.

24. M. Prideaux, Conserving Cetaceans: The Convention on Migratory Species and its relevant Agreements for Cetacean Conservation, WDCS, Munich, Germany, 2003, 24 pp.

25. G. Bearzi, Interactions between cetacean and fisheries in the Mediterranean Sea. In: Nortarbartolo di Sciara (Ed.), Cetaceans of the Mediterranean and Black Seas: state of knowledge and conservation strategies. A report to the ACCOBAMS Secretariat, Monaco, February 2002. Section 9, 20 pp.

26. R.R. Reeves, A.J. Read, G. Notarbartolo di Sciara, Report of the Workshop on Interactions between Dolphins and Fisheries in the Mediterranean: Evaluation of Mitigation Alternatives. ICRAM Workshop, Rome, Italy, May 2001. Doc. SC/53/SM3 presented at the 53rd Meeting of the International Whaling Commission, London, July 2001.

27. A.A. Silantyev, Black Sea Coast of the Caucasus in Agricultural and Commercial Respects. Issue 1. Dolphins Fishery off the Caucasian Coasts. Department of Agriculture, St Peterbourg, (1903).

28. V. Pavlov, A. Artov, T. Zhuravleva, Impact of fishing on Black Sea dolphins off the Crimea coasts. Pp. 41-43 in: B. Öztürk (Ed.), Proceedings of the First International Symposium on the Marine Mammals of the Black Sea (Istanbul, Turkey, 27-30 June 1994), ACAR Matbaacilik A.S., Istanbul, 1996.
29. S.G. Bushuyev, Depletion of forage reserve as a factor limiting population size of Black Sea dolphins. Pp. 437- 452 in: Ecological safety of coastal and shelf areas and a composite utilization of shelf resources, Proc. Marine Hydrophysical Institute, Sevastopol, 2000.

30. M. Klinowska (Comp.), Dolphins, Porpoises and Whales of the World. The IUCN Red Data Book. IUCN, Gland and Cambridge, viii + 429 p, 1991.

31. B. Öztürk (Comp.), Black Sea Biological Diversity: Turkey. UN Publ., New York, 1999.

32. Birkun, A., Jr., Interactions between Cetaceans and Fisheries in the Black Sea,. In: G. Notarbartolo di Sciara (Ed.), Cetaceans of the Mediterranean and Black Seas: state of knowledge and conservation strategies. A report to the ACCOBAMS Secretariat, Monaco, February 2002, Section 10, 2002.

33. S.V. Krivokhizhin, A.A. Birkun, Jr., J.V. Nessonova, Prey species of Black Sea cetaceans. P. 229 in: P.G.H. Evans, R. Pitt-Aiken and E. Rogan (Eds.), European research on cetaceans - 14 (Proc. 14th Annual Conf. European Cetacean Society, Cork, Ireland, 2-5 Apr 2000), ECS, Rome, 2000.

34. D.P. Andrianov, V., Bulgakova, The factors determining the abundance of the Black Sea anchovy. Pp. 13-15 in: B. Öztürk (Ed.), Proceedings of the First International Symposium on the Marine Mammals of the Black Sea (Istanbul, Turkey, 27-30 June 1994), ACAR Matbaacilik A.S., Istanbul, 1996. 